\title{
The Way of the Mystic: The Sanjuanist stages of the spiritual path
}

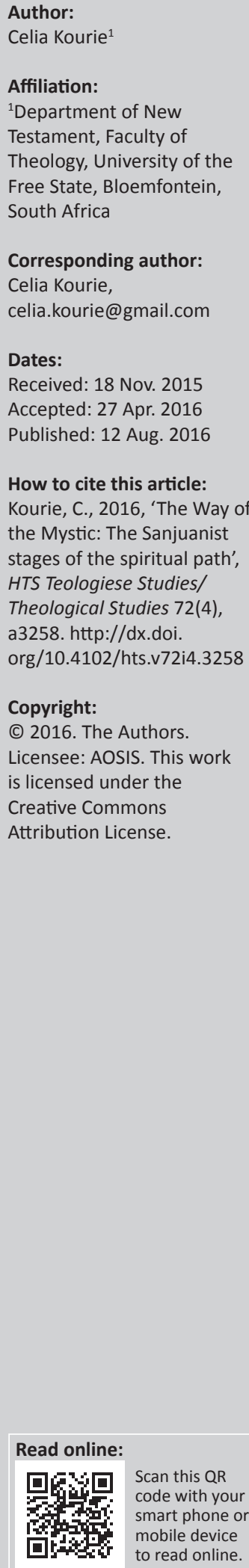

A major conceptual dynamic in all major religious traditions is the need for purification and transformation of the individual in order to effect integration and maturation of the personality in the divine. Although the means by which this purification takes place differs according to the cultural and religious configurations of any given tradition, nevertheless a recurring image is that of an inner and outer odyssey. A major example is the threefold path of John of the Cross, which presents a psycho-spiritual journey by which 'divine osmosis' can be realised, passing through the 'dark night of the soul', and culminating in 'spiritual marriage'. Although not accepted by many theoreticians and practitioners of mysticism, nevertheless the value of the Sanjuanist schemata still holds sway in contemporary society.

\section{Introduction}

A long-established tradition in the history of mysticism is the fact that the mystical path comprises different stages or gradation, leading to even higher levels of consciousness. There has to be an inner death with respect to selfish attitudes and limited contingent ways of relating to the world. For this reason, the major religious traditions posit the necessity for a path of purification and transformation in order to effect integration and unification of the personality in the Divine. Social, emotional, moral and spiritual growth lead to maturation of body, mind and spirit and support the Pythagorean adage that the life of wisdom is the life of discipline. This is a major conceptual dynamic in all major religious traditions. Progress and growth, including exterior and interior purification in order to set aside attachments to the transitory and ephemeral are therefore integral to the mystical way, although the means by which this is attained may differ according to the diverse systems of belief.

True mystical experience is characterised by a sense of an immediate contact with the transcendent. Such an experience often exhibits a feeling of timelessness, bliss or serenity, union with the Divine, or the Ground of Being, or Ultimate Reality, depending on the type of mysticism under investigation, and whether its predilections are theistic or monistic. ${ }^{1}$ It is my contention that the potential for mysticism is innate, and the possibility for a diaphany of the divine is ever-present. This may necessitate a path of purification in order to effect what could be called a divine 'osmosis'. For this reason, mystics across the various religious traditions have in many instances embarked upon a process of transformation - a mystical path that leads to integration and maturation. ${ }^{2}$

In the light of the above, the aim of this endeavour is: firstly, to offer a few examples of the mystical way across some of the major religious traditions; secondly, to delineate the stages of the mystical way as promulgated by the sixteenth century mystic, philosopher and theologian, John of the Cross (1542-1591); and thirdly, to evaluate the last-named in the light of twenty-first century spirituality. Furthermore, we now live in an inter-spiritual age, in which mutual understanding and dialogue have largely replaced former attitudes of domination, triumphalism and colonialism; consequently this essay will also reflect a greater understanding of the 'other', in as far as this contributes to the discussion at hand. ${ }^{3}$

\section{The mystical way}

Of necessity, the following is but a brief survey of the mystical way in some of the world's religious traditions. Space does not allow for an in-depth survey of these spiritual paths; suffice it to say 1.See Kourie (2015:4ff) for a discussion of recent theories and definitions of mysticism.

2.A discussion of the diversity of paths, including 'no-path' is outside the purview of the present endeavour. See Borchert (1994) for an illustration of these alternative ways of mysticism.

3.See, inter alia, Waaijman (2008), McGinn (2011), Hense (2011) and Kourie (2011) for further elaboration regarding the nature of interreligious exchange and the contemporary phenomenon of interspirituality. 
that even a brief foray into the mystical philosophy of world religions leads to a recognition of the priority of development and growth in the path to the Divine.

In Hinduism ${ }^{4}$ the Yoga Sutras of Patanjali (c. $400 \mathrm{CE}$ ) are a systematisation and clarification of ascetic and contemplative practices, practiced in India from time immemorial (Eliade 1969:7). The eight limbs of this Raja Yoga describe, inter alia, the five yamas, restraints; the niyamas, disciplines; the asanas, yogic postures; and the pranayamas, breathing exercises - all of which facilitate transformation. In addition, mental practices, such as pratyahara, the withdrawal of sense awareness of the world of ordinary perception; dharana, onepointed concentration; and dyana, meditation; help effect the attainment of Samadhi, blissful union with the divine. Concentration is the first goal: ' ... collecting and focusing the mind and spirit. People begin the yogic enterprise scattered, distracted, the slaves rather than masters of their minds' (Carmody \& Carmody 1996:42). Consciousness is in a state of disequilibrium, because of its fluctuating character, characterised by 'sense impressions and memories generated in the embodied state' (Ganeri 2012:231). The recollection of the faculties implies a '... reformation of the moral life and moving beyond it into spiritual reform, a reconstitution of the mind' (Carmody \& Carmody 1996:42). As a result, the teeming flow of thoughts and emotions is simplified, and its velocity diminished. Control of consciousness, effected by the practice of Patanjali's stages of ethical, physical and mental control, leads to '... the final stage of absorbed concentration (samadhi)' leading eventually to 'final liberation' (moksha) (Ganeri 2012:232).

The aforementioned reconstitution of the mind is a powerful leitmotif of Buddhist mysticism. The well-known eightfold path of Buddhism epitomises moral and spiritual progress, the constituents of which are as follows: right views, sammaditthi; right resolve, sammasankappa; right speech, sammavaca; right conduct, sammakammanta; right livelihood, samma-ajiva; right effort, sammavayama; right mindfulness, sammasati; and right concentration, sammasamadhi. It is important to note that 'right' does not mean 'moral' in the Western sense of the word, but rather that which is conducive to liberation. The Buddhist path aims at a life of physical, emotional and cognitive simplicity, and following what is 'right' will effect liberation from the cycle of karma, the results of action; dukkha, sorrow or state of dissatisfaction; and samsara, the cycle of rebirth, resulting in nirvana (Katz 1983:41-42). Various paths, margas, which elucidate the eightfold middle path in detail, are found in the major traditions of Buddhism. Of central importance is the 'stripping of conceptual excess and physical luxury' which helps 'prevent the proliferation of mental fabrications' (Kruger 1989:83). ${ }^{5}$

4.In classical Hindu society, the lifespan of a male comprised four distinct stages: firstly, brahmacarya, the student life, characterized by sexual abstinence; secondly, garhasthya, the situation of the householder, involving marriage, parenthood and appropriate service to the community; thirdly, vanaprastha, the life of the forest appropriate service to the community; thirdly, vanaprastha, the life of the forest dweller, characterized once again by celibacy and also solitude; and finally, wife, bot totally detached at this stage of life from all material possessions, and prepared for final liberation.

5.See also Kruger (2007:88-89) for an analysis of the development and purification of consciousness according to Vasubandhu and the Yogacara School of Mahayana Buddhism.
In the Theravada classic, the Visuddhimagga, the fifth century wisdom teacher, Buddhaghosa, discusses in detail 40 topics of meditation that will facilitate progress on the path and effect liberation (Carmody \& Carmody 1996:70-73). The essential elements of this magnum opus can be summarised as virtue, concentration and understanding, and can be seen as an exposition and 'analytical elaboration' of the essence of the first chapter of the Dhammapada, in the Theravada canon. Buddhaghosa shows us that in order to gain liberation, we need to '... orient our beings toward the mental light of suchness, the world as it really is; ... [and] concentrate our awareness to best facilitate the dawning of that mental light; and how to estimate the knowledge that we gain' (Carmody \& Carmody 1996:75). Thus the ensuing meditation aims to '.. purify the mind so that it becomes utterly realistic ...' enabling 'the potential self-possession of the enspirited being'; this is not a solid self, but 'rather an "emptied" or extinguished former candle of desire that now exists without conditions, fully free' (Carmody \& Carmody 1996:76).

In Zen Buddhism, the use of a koan is one means of effecting the aforementioned state of freedom. The essence of the koan is a paradoxical, apparently senseless assertion, or unanswerable question, the purpose of which is to irritate the mind and to move beyond its rationality. Because the koan is paradoxical and inimical to conventional discourse, it does not succumb to logical analysis, but rather exhausts the rational mind and effects a breakthrough to enlightenment. ${ }^{6}$

The Buddhist path emphasises gradual development, and the various stages are not rigid sequences, but refer rather to stages of human maturity. In summation, the aim is the purging of desire and cessation of illusory existence, particularly the overcoming of the erroneous notion of self, known as the doctrine of anatmavada.

In Judaism, the mystical path, according to Philo (20 BCE-41 CE) comprises three stages: firstly, asceticism, the aim of which is to conquer the lower passions; secondly, knowledge, which includes a knowledge of heavenly wisdom; and thirdly, union, when the God-given nature partakes in the royal virtue and receives and abides in God's gifts. Merkavah (Chariot) mysticism, which originated in the Talmudic period, was practised by contemplatives, the 'Riders of the Chariots' who engaged in the ascent to the heavenly halls, by following certain techniques, leading to the vision of God and his holy angels:

You may perhaps know that many of the Sages hold that when a man is worthy and blessed with certain qualities and he wishes to gaze at the Heavenly Chariot and the halls of the angels on high, he must follow certain exercises. He must fast for a specified number of days, he must place his head between his knees, whispering softly to himself the while certain praises of God

6.cf. Pierce $(2012: 243)$ who refers to the ancient Japanese chant, composed by Master Hakuin (1685-1768), called The Song of Zazen: 'Not realizing that Truth is so close, beings seek it far away ... It is like one who, while being in the midst of water, cries out for thirst. It is like the child of a rich household who gets lost in a poor village'. 
with his face towards the ground. As a result he will gaze in the innermost recesses of his heart and it will seem as if he saw the seven halls with his own eyes, moving from hall to hall to observe that which is therein to be found. (quoted in Jacobs 1986:493)

The pursuit of the mystical path in Kabbalah and Hasidic mysticism is outside the purview of this brief survey; suffice it to say that the mystical quest in Judaism for direct experience of the Divine, '... never leaves the further historical course of that quest. Through all its legal and symbolic permutations, Jewish spirituality stays coherent through fidelity to its beginnings on Sinai, its conviction that its God moves in its history, and its love of the divine fire, the furnace of holiness' (Carmody \& Carmody 1996:183). In a similar vein, the path of Jewish mysticism is very practical. Mystical experiences cannot stay at the level of personal emotion; rather, '... experience must become the foundation for active celebration of the more formal Jewish ritual as well as the performance of mitzvahs, good deeds in history' (Pawlikowski 2012:258).

Sufism ${ }^{7}$ teaches its followers that the believer, following the inner path, salak al-tariq, must traverse certain 'stages' in order to reach the final goal of divine illumination. These are: repentance, patience, gratitude, hope, holy fear, voluntary poverty, abnegation, dependence on God, and love, including passionate longing for and intimacy with God, casting aside all that is of this world so as to glorify God alone. Rigorous self-discipline is demanded of the Sufi. Sufi monasteries, the khanaqahs, helped effect this process. The probationary period of the incipient mystic was usually 3 years. In the first year, the Sufi novice devoted himself to the service of humanity; in the second, to the service of God; and in the third to constant vigilance of his thoughts. By following the 'way', the tariqa, and moving upward through the various stages, the insinuations of the lower soul, the nafs, are eliminated and the experience of unity with Allah, fana, is affected. Of significant relevance is the fact that the Sufis, although they loved the diverse manifestations whereby the Divine engaged with human beings, and adhered to the admonition to live well, nevertheless, were 'philosophers of the divine One more than anthropologists of the cultural many' loving 'the transcendence of God, the unlimited horizon, that offered freedom from the crush of this-worldliness' (Carmody \& Carmody 1996:205). Furthermore, the importance of the Koran as the source of the Way or the Tariqah cannot be overestimated:

Only the Sufis have, in fact, been able to cast aside the veil of this celestial bride, which is the Quran, in order to reveal some of her beauty, which it hides from the eyes of those who are strangers to her. (Nasr 1987:8, quoted in Carmody \& Carmody 1996:266)

In the Christian tradition, the idea of growth and progression is present in scripture, particularly in the writings of Paul. Paul speaks of two stages, namely infancy and adulthood

7.Although Sufism post-dates Christianity, it is included at this juncture, as the latte will be dealt with in more detail below and also in the Sanjuanist analysis of the mystical path. with regard to growth in Christ (Eph 4:12-16). In addition, Hebrew 5:13-15 'formed the scriptural basis for subsequent reflection on the experimental dimensions of this process of spiritual growth ... by which one attained maturity in Christ' (McGonigle 1993:963) In the writings of the early church fathers, the Neoplatonic categorisation of the active and the contemplative life was developed by Clement of Alexandria (c. 150-214 CE) and Origen (185-254 CE). Asceticism, knowledge and union are the means by which the perfect gifts of God are given to the devotee, resulting in a participation of the royal virtue. In addition, the metaphor of climbing a mountain was also used to describe the progress of the Christian life. The active life comprised the exercise of the moral virtues, which in turn led to purification, and the correction regulation of the soul. The contemplative life consisted of the highest human activity, namely the contemplation of God and therefore the practice of the theological virtues of faith, hope and charity. Evagrius Pontus (344-99 CE) accepted this twofold division. The first stage aimed at moral perfection and dispassion. The second stage Evagrius subdivided into a lower and higher form of contemplation. For Evagrius, the Christian way comprised, respectively, those involved in the practical life; those attentive to God's presence in contemplation of creation; and those whose lives were devoted to God alone. The three stages comprised even deeper levels of God-consciousness, leading eventually to deification. In The Celestial Hierarchy of Pseudo-Dionysius $^{8}$ (c. 500) the terms 'purgation', 'illumination', and 'union' are first found, as representing the means to mystical union. This classical division was further developed in the Medieval period, for example, Bernard of Clairvaux (1090-1153); Catherine of Siena (1347-1380); Ignatius of Loyola (1491-1556); Teresa of Avila (1515-1582); and notably John of the Cross (1542-1591), whose delineation will be dealt with in detail below. Contemporary spirituality does not emphasise this threefold demarcation so markedly, although it is accepted that it has had significant influence on the development of the Christian spiritual tradition (Tyler 2005:626). Space does not allow a detailed discussion of spiritual writers whose views differed from those listed above; suffice it to say that some, following the tradition of Bonaventure, considered the three paths to refer to 'diverse aspects of a single process of sanctification that is repeated in the lives of believers in accord with their varying needs for purgation, illumination, and union at different points in their own journey to spiritual maturity' (McGonigle 1993:964). Worthy of note is the fact that although the threefold way was generally accepted in Catholic thought, there were exceptions. For example, the teaching of Miguel de Molinos, 'who held that the concept of the three ways was absurd', was condemned by Pope Innocent XI in 1687 (McGonigle 1993:963-964). In addition, contemporary Catholic theology and spirituality also has its dissenters, inter alia Rahner (1967). Interest in the threefold delineation in terms of psychological development comes from, inter alia, Fowler (1996) who,

8.Anonymous 6th century author, originally thought to be the convert of Paul in Athens (Acts 17:34). As a result he is often known as Pseudo-Dionysius, or PseudoAthens (Acts 17:34). As a result he is often known as Pseudo-Dionysius, or Pseudo-
Areopagite (Perrin 2007:250). See also, Louth, A 1989. Denys the Areopagite. London: Geoffrey Chapman. 
building on the work of Carl Jung and Erik Erikson, suggests a sevenfold division of faith development which is integrated into psychological development (Tyler 2005:627). By way of summary, in spite of the above mentioned contrary views, nevertheless, 'The paradigm of the three ways offers the opportunity to discuss the diverse aspects that seem to constitute the process of sanctification necessary for every person in order to attain spiritual maturity' recognizing the 'unique paths, within the broad threefold pattern of spiritual growth, that God invites individuals to walk...' (McGonigle 1993:965).

Against this background, the Sanjuanist stages of the mystical path will now be examined. ${ }^{9}$

\section{Sanjuanist stages of the mystical way}

The major works of John of the Cross (1542-1591) namely: Ascent of Mount Carmel (Subida del Monte Carmelo); Dark Night of the Soul (Noche Oscura); Spiritual Canticle (Cantico Espiritual); and Living Flame of Love (Llama de Amor Viva), ${ }^{10}$ develop at length the threefold path: the purgative way; the illuminative way; and the unitive way.

By way of introduction, a few preliminary considerations are in order.

Firstly, John's works illustrate his deep insights into theology, psychology, spiritual direction, and mysticism. Although John drew from many sources, ${ }^{11}$ nevertheless, the Bible was his ' ... living and unfailing wellspring. Its waters pervade the entire being of this mystical thinker, poet and writer. The bible was his hymnal, his meditation book, a book for travel, for contemplation, and for writing' (Kavanaugh \& Rodriguez 1991:35). ${ }^{12}$ Secondly, in order to understand the mystical thought of John of the Cross, it is necessary to be familiar with the scholastic psychology which undergirds his work (cf. Howells 2002). Within this scheme, the person is seen to comprise a tri-partite division of body, lower soul, and higher soul, or spirit. The person is a psychosomatic unity of body and soul which are interdependent. By means of the body, contact with the world is made, specifically through the exterior corporeal senses. These senses are in turn governed by the interior or sensitive part of the soul. This is the lower soul, in which the natural desires and passions reside, the former originating in bodily needs, and the latter, namely joy, hope, fear and grief, originating in the soul itself. In addition, this lower or sensitive soul has an interior

9.Certain aspects of this discussion were introduced in Kourie (1993).

10.The following abbreviations will be used when citing these work of John of the Cross: A: Ascent; DN: Dark Night; SC: Spiritual Canticle (second redaction); LF: Living Flame.

11.Inter alia, Aquinas, Augustine, Neoplatonism, German, Rhineland and Spanish mystics (Kavanaugh \& Rodriguez 1991:35).

12.John utilised three main hermeneutical keys for reading the Bible. 'First the bible offered him an excellent expression of his own spiritual experience. Second, he found in the Bible a confirmation of his theological argument. Finally, he enjoyed and followed the contemporary practice of using scriptural passages in an accommodated sense' (Kavanaugh \& Rodriguez 1991:35). corporeal sense, namely the imagination, which assimilates impressions derived from the senses. The higher part of the soul, which John also calls the spirit, is the seat of the rational faculties, namely, understanding, memory and will. Logical thinking and comprehension, the recording of data by the memory, and the operation of the will by volition are considered spiritual acts in John's scholastic psychology. The hierarchy of faculties and operations is presided over by the final arbiter and governor, the will. Moral living and the practice of virtue, therefore, consists not only in developing and maintaining the hegemony of the rational powers over the sensitive part of the soul, but also in integrating natural desires and passions into the higher part of the soul, where they can be rationalised and diffused into the spiritual faculties. The most noble of all spiritual acts is the act of loving. Thirdly, the various stages, and the phenomena associated with them are not necessarily experienced by all mystics, or in the same manner. Individual personalities affect the manner in which the path is experienced. There are what could be called 'solar' and 'nocturnal' personalities, the former emphasising the more positive aspects of the mystical life, whereas the latter experiencing more acutely the dark nights along the way. Therefore, it cannot be determined if a certain person has reached a particular stage of the mystical way merely on the basis of the presence or otherwise of a given phenomenon usually associated with the stage in question. The stages provide certain criteria or guidelines, but cannot be taken de facto as the only judge. Fourthly, these stages are not to be understood as occurring in strict rectilinear succession. The process is more cyclical and dialectical than linear, and therefore there is a certain amount of interaction and intermingling between the various stages. ${ }^{13}$ A fifth point of clarification concerns the nature of conversion or spiritual awakening. This can happen in very diverse ways. It is often, but not necessarily, preceded by an existential awareness of psychological disequilibrium and alienation from God. John of the Cross delineates the various characteristics associated with such a state, namely, the weakening and darkening effect of unruly appetites on the soul; the lack of integration in the affective sphere because of competing drives and emotions; and the clouding of the mind because of inordinate appetites (A 1,8. Kavanaugh \& Rodriguez 1991:135-137). The awakening of the transcendental consciousness has been described by Underhill ([1911]/1961: 176-177) as ' . . a disturbance of the equilibrium of the self, which results in the shifting of the field of consciousness from lower to higher levels' in which the self '... slides gently, almost imperceptibly, from the old universe to the new'.

\section{The purgative way}

The purgative way is primarily associated with the state of 'beginners'; however, in John's use of this term he refers to those '... dedicated individuals who have already resolutely decided to direct their lives to God ... who already have a

13.John refers to the fact that his path is not strictly linear. He often uses the term ordinariamente to speak about how people experience their spiritual lives (Feldmeier 2006:74). 
certain degree of dedication ... they have started the journey to perfection and Christian maturity' (Doohan 1995:63). They have felt the 'gravitational pull' of the divine call (Kurian 2000:173), and as serious followers of the spiritual way, they are deeply committed to God, and experiences God's grace (Feldmeier 2006:50). They are '... already detached to a great extent from the temporal things of this world' however 'not yet being strong in spirituality [they] develop numerous imperfections' (Kochumutomm 2011:15). As a result, John is critical of beginners: 'A certain kind of secret pride is generated in them that begets a complacency with themselves and their achievements' (DN 1,2,1, Kavanaugh \& Rodriguez 1991:362). They believe that 'the focus of their spiritual lives is unconsciously gratification of the self' (Feldmeier 2006:50). Detachment, not only from worldly satisfaction, but also from spiritual consolations, is crucial at this stage, particularly from the externals of worship and religion which only serve to feed the ego: 'There is an inescapable tendency in all those who seek to follow the spiritual path to place much faith in their good works, asceticism, practice of virtues and other devotions because such accomplishments make them appear worthy in their own eyes' (Kurian 2000:206).

What is the aim of this asceticism? The main task of the purgative way, according to John of the Cross, is to actively engage in '... the trials and bitterness of mortification and in meditation upon spiritual things' (SC 22,3. Kavanaugh \& Rodriguez 1991:560). Such purgation is necessary so as to '... find her Bridegroom and be united to him in this life through union of love insofar as possible' and 'enter within ... in deepest recollection and let all things be as though not' (SC 1,6. Kavanaugh \& Rodriguez 1991:480). Rigorous asceticism and effort is needed in order to disentangle the self from its selfimportance and effect release from the conceptual cocoon that is so firmly entrenched. Therefore the self-absorbed ego has to be cauterised and the desires of the mind and heart that ensnare and capture the individual must be purified.

John calls this first step in the purgative way the active night of the senses. Tenacity, perseverance, and the ability to transcend the disturbing activities of the imagination and intellect are prerequisites for this journey. Thus, the purgative way helps the individual restore proper equilibrium to life, so that actions are no longer determined by the pursuit of pleasure and avoidance of pain, but rather by reason and the divine will (Payne 1982:143). Because the beginner is still 'spiritually narcissistic and attached to sensory experience, there has to be an emptying of the sensory life in prayer' (Feldmeier 2006:54). It is first and foremost 'the denudation of the soul's appetites and gratifications' (A1.3,4. Kavanaugh \& Rodriguez 1991:123). Such active purification effects the realisation that, 'The continuity of our human identity is no longer grounded in the memory of a life that is realized within the boundedness of the created self, but in the memory of God's eternal love....' (Blommestijn, Huls \& Waaijman 2000:100).

The active night of the senses is but the beginning of the inner odyssey of the mystical path and of itself is not sufficient to effect transformation of the human personality. Although rigorous asceticism is a sine qua non in order to begin the ascent of the mount, nevertheless the naughting of the ego cannot be affected by the devotee's efforts alone. Hence, the need for the passive night of the senses, which in fact forms a bridge between the purgative and the illuminative stage. Characteristic of the passive purgation of the senses is a marked inability to meditate, and a loss of satisfaction in spiritual practice, which causes confusion and distress to the disciple who has so recently embarked on the mystical journey. Drawing on Tauler, ${ }^{14}$ John urges the devotees to remain in God's presence in 'loving attention and a tranquil intellect even though they seem to be idle ... [remembering] that pacification of the soul (making it calm and peaceful, inactive and desireless) is no small accomplishment' (A2.15,5. Kavanaugh \& Rodriguez 1991:199). Thus, inner detachment is more important than physical deprivation. Excessive mortification can have the opposite effect to that intended, namely by focusing undue attention on the body and its desires. There is always the danger of an egocentric concern with moral and spiritual progress, and self-glorification, which can easily creep into the spiritual path.

It is clear that John is actually leading the devotee to a stability of consciousness whereby one acts without attachment to the fruits of one's actions. ${ }^{15}$ The one who renounces reward is the true renunciate. John is advocating detachment, which results in even greater joy in created realities, because the adherent is practicing disinterestedness - not in a negative sense, but freedom from both attraction and aversion. ${ }^{16}$ Detachment effects a pure joy in created things, which is totally opposed to, the '... transient and bittersweet pleasures granted to those who continue to view the world from a limited, egotistical standpoint' (Green 1986:34). Often John's teaching on detachment and deprivation is seen as extreme, however, '... this apparent negativity needs to be seen in the light of the renewal and growth that John seeks' (Doohan 1995:67). ${ }^{17}$ A positive result of the purifications experienced at this stage therefore is a sense of openness, in which human existence, whatever the texture of its surface, reaches new depths, and consequently new meaning which helps eliminate the metaphysical duality which is deeply rooted in egocentric patterns of behaviour. Knowledge of God at this stage in John's words is by means of ' ... knowing God through what he is not rather than through what he is ... and journey ... by way of the denial and rejection of natural

14.Persist in this interior captivity and abandonment, diligently taking care that you desire nothing at all without necessity; not leaving the house needlessly, not desire nothing at all without necessity; not leaving the house needlessly, not
thinking on vain things, and speaking only when necessary. Attend to all thy thinking on vain things, and speaking only when necessary. Attend to all thy
projects and works with extreme care and learn what God expects of thee and in what manner. Let your prayer be continual, neither adding to it nor shortening it in a word, Thy will be done' (Tauler, Institutions, ch 22, in Arintero [1951]/1978:101)

15.This motif also comes powerfully to the fore in the Bhagavad Gita, which, in similar vein, points to the freedom of detachment: 'When work is done for a reward, the work brings pleasure or pain, or both, in its time; but when a man does work in Eternity, then Eternity is his reward'. It is a question of renouncing 'the self'; as a result of this, any work can be undertaken, 'because it will not bind us' (BG 18:12, Griffiths 1995:304).

16.This results in evenness of mind, which in the Bhagavad Gita, is samatva, equanimity (Kourie 2013:265)

17.In addition, one needs to remember that a view prevalent in the medieval era set earthly realities against spiritual growth (cf. Doohan 1995:67). This is in contrast to a more holistic approach to spirituality in the 21st century. 
and supernatural apprehensions' (A3.2, 3. Kavanaugh \& Rodriguez 1991:268). At this point of growth, a new form of knowledge is being introduced which does not come through the normal avenues of cognition. This knowledge, in contrast to the intellectual mode, is secret, obscure and nonconceptual. It is, in John's terminology, infused or mystical knowledge. There is a denuding of the mind, in order for the inner depths of the person to be filled with divine light. The emptying of the mind does not, however, indicate that John's mysticism is totally anticognitive. Therefore, the contention of Werblowsky (1966:179) that John ' ... seeks not the knowledge of heavenly things, but the nakedness of the soul bereft of all knowledge' is incorrect. Werblowsky, having made this categorical statement, then draws the conclusion that John's teaching implies the annihilation of reason, will and the other faculties of the soul. This view is untenable, stemming as it does, from a misunderstanding of the doctrine of John. As Green (1986:29) points out, 'Werblowsky fails to distinguish adequately here between different types of "knowledge" or "cognition". There are many types of intelligibility, meaning or knowledge, all equally valid on their respective levels'. Mystical knowledge points to the fact that 'rational consciousness [is] only one kind of consciousness; there are other dimensions to our life, other kinds of truth and knowledge' (Green 1986:29). A more careful and comprehensive reading of John's works reveals that he does not suggest the annihilation of natural cognitive abilities; his aim is rather to lead the adherent to a new type of apprehension different from rational and empirical modes of thought, but nevertheless a very real kind of knowledge. By means of the dark night of unknowing all distinct thoughts and images are eliminated and a new knowledge is received in the innermost substance of the human psyche, the ground or essence of the person's being (Payne 1982:82-85; Merton 1981:83). Relating the foregoing to the insights of Heiddegger (1966:55), such new knowledge effects 'Releasement (Gelassenheit) towards things and openness to the mystery [which] grant us the possibility of dwelling in the world in a profoundly different way. They promise us a new ground and foundation upon which we can stand and endure'.

The way of purgation, encompassing as it does the active and passive purification of the senses, opens up deeper areas of the personality - areas that are normally inaccessible to normal consciousness. The purification process systematically strengthens the innermost layers of the psyche and spirit, enabling the senses to be re-educated and 'is part of a process of integration whereby our inner fragmentation is overcome and all aspects of our human existence are brought together in a self-gift to God (Doohan 1995:69).

The believer is now no longer merely a beginner, but in the terminology of John of the Cross, is now a proficient, and can advance into the illuminative way of contemplation.

\section{The illuminative way}

It is important to remember that purgation and illumination often coexist and are complementary to each other as dark and light aspects of the mystical consciousness. There is a 'cyclical ascent moving up in spirals that pass through the same succession of purification and illumination on higher levels' (Dupre 1981:75). At this stage, there is a new kind of radiance within the personality of the mystic: a flooding of the personality with new light. As a result of this elevation of consciousness, daily life and work become more efficient, more integrated. At this point of the illuminative way, meditation becomes contemplation, or the prayer of quiet; the imagination and faculties are no longer bound to discursive thought; and there is a relative state of peace and contentment, interrupted occasionally by moments of profound religious ecstasy or pain. The passive night of the senses has resulted in:

... a certain reallocation of the individual's cognitive resources through the partial subjugation of the inordinate appetites. Now the proficient becomes more and more attuned to a whole realm of experience previously impeded by his preoccupation with the sources of sensory pleasure. He develops a clearer and more objective perception of the world around him. (Payne 1982:150)

The joy and peace experienced at this stage are calm and serene and a source of power, in contrast to excitable emotionalism. The adherent now has a foothold in the real world that has been the object of the mystical path. Openness to this realm, as a result of contemplation, facilitates a greater ingression of the divine energy and a transformation of the deep levels of the psyche. 'In this new state, as one liberated from a cramped prison cell [the soul] goes about the things of God with much more freedom and satisfaction of spirit and with more abundant interior delight than it did in the beginning before entering the night of sense' (DN2.1, 1, Kavanaugh \& Rodriguez 1991:395). Here, one is 'more attuned to a realm of reality that he or she was unaware of before. One's gaze on the world has shifted, as has one's relationship to it' (Perrin 2007:253).

It is at this stage that quite often the epiphenomena associated with mysticism occur. The experiential contours of this stage are not ignored by John. In psychological terms the proficient's unusual experiences could be described as hypnagogic phenomena which involve the translation of psychic activity into visual, verbal and conceptual images (Payne 1982:154, fn 33). In accordance with traditional mystical theology, John does not attribute much value to the epiphenomena associated with the mystical stage of illumination. In general, he maintains that the more spiritual and interior the mystical experience, the more it is of benefit to the adherent, and he sees scant intrinsic value in extraordinary phenomena as such. The reasons he discusses these occurrences is to warn his readers against becoming too attached or distracted by ecstasies, visions or other such phenomena (cf. N2.2,3. Kavanaugh \& Rodriguez 1991:397). Although it is not false mysticism to have such experiences, nevertheless it is false mysticism to make them an integral component of mysticism. Detachment from spiritual gifts and renunciation of psychic powers is a sound test of authentic mysticism. ${ }^{18}$ In a similar vein to the detachment

18.In Buddhism such powers, siddhis, often paranormal, are never to be sought for themselves. They can distract the adherent from the goal of wisdom in emptiness. In themselves. They can distract the adherent from the goal of wisdom in emptiness. In early Buddhism, the misuse of psychic powers for self-glonification effected expulsion from the community. The Yoga Sutras of Patanjali also minimise the importance of sights, sounds, appearances and sensations that may arise during meditation, and warn of the danger of being captivated by these wayside experiences. 
that John urged with respect to the senses, so too with the 'extraordinary phenomena' that may occur in the spirit, namely the 'visions of the soul' (Perrin 2007:253). The admonition of John of the Cross to reject the various apprehensions occurring at this stage is coupled with his insistence that the proficient should remain in the 'darkness' of faith, hope and charity (N2.27,7. Kavanaugh \& Rodriguez 1991:255).

Such activity during this stage of illumination comprises the active night of the spirit, where faith is the only guide. The active night 'consists in an individual's efforts to purify the spiritual faculties - intellect, memory and will - of their false or limited contents and methods of knowing God' (A2,6,1. Kavanaugh \& Rodriguez 1991:166) (Doohan 1995:73). ${ }^{19}$ Purity of heart, selflessness and abandonment are particularly important at this juncture - remaining in the 'darkness' of faith, hope and charity, which are the only real means to union with God. Therefore, John urges his readers to walk in faith, and not to cling possessively to either natural knowledge or to extraordinary experiences. This night of the spirit is active, because the believer endeavours to empty and purify the intellect, memory and will of all that is not God. Thus, a certain effort is necessary to enter into ultimate detachment and emptiness of spirit, which in its turn necessitates elimination of pride and self-sufficiency, and detachment from the things of time and sense. The accommodation of the senses to the spirit leads the adherent to the realisation that 'only God's loving grace can achieve the fullness of life that is desired' (Perrin 2007:254).

In order to effect further purification of the inner recesses of the soul, a second passive night is necessary, the passive night of the spirit, often referred to as the dark night of the soul.

The trenchant nature of this night is clearly depicted by John: '...the soul not only suffers the void and suspension of ... natural supports and apprehensions... but is also purged by this contemplation ... [which] 'annihilates, empties and consumes all the affections and imperfect habits the soul contracted throughout its life (N2.6,5. Kavanaugh \& Rodriguez 1991:405). Strong words indeed! Thus, this night comprises the purification of the faculties, affections and feelings, both spiritual and sensual, both outward, and inward, which results in an inner darkness of understanding. The mystic must be cleansed of everything that is not of God. The trials of the passive night of the spirit are far worse than any experienced so far. What is in actual fact an inflowing of God's light and wisdom effects excruciating suffering: This dark night can last several years, as was the case, for example, with Teresa of Avila. Individuals may feel that God has rejected them; 'they are oppressed by their poverty, misery, helplessness and abandonment' (Doohan 1995:75). 'John's advice for this period is for the soul to absolutely abandon itself in faith, hope and love, to sustain itself through devotion and prayer in God's often perceived absence....

19.Doohan (1995:73) speaks of the need to relinquish the 'idols' of our theories and concepts about God: '... the dark night of faith purifies the intellect of attachment to its natural objects and urges the disciple to be open to knowledge that faith gives'.
John repeatedly reminds us that this same light, which can be experienced as painful and blinding, is also the light of union' (Feldmeier 2006:56).

This process holds, however, unique opportunities for advancement, if the believer accepts and utilises such suffering. Often the purificatory value of the trials and sufferings of this stage is not sufficiently appreciated for its true worth, and opportunities for spiritual growth can be lost by a lack of recognition of the importance of this stage. It is important to take note of the fact that the dark night of the spirit is not a uniform experience. It is rather to be seen as a generic appellation for the negative period that normally intervenes between the illuminative and the unitive way, often characterised by lassitude, and the temptation of complicity of the spirit with the lower appetites. John of the Cross is at pains to point out that it is within this experience of darkness that desire is purified and freed. The listlessness and ennui that can be almost overwhelming are in fact the mediating forces by which desire is transfigured. The apparent divine absence is to be seen as a final purification before the soul is fully merged in God. The dismantling and restructuring of the personality in all its complexity, or, otherwise stated, the struggle of the spirit with recalcitrant matter, can be described in alchemical terminology as the transmutation of the base metal of the psyche into pure gold. The kenotic nature of the dark night typifies an inner death, a death to egocentricity, with its limited, contingent ways of relating to the world, and drawing one away from the fragmentation and lonely atomisation of the self into the deeper levels of inner connectedness.

It is important to recall that John is:

... describing an existential process, not expounding a metaphysical epistemological theory; too readily classifying him as a quasi-Hegelian, or a 'death-of-God' theologian can lead to a biased and one-sided reading of his texts. (Payne 1982:165)

Furthermore, the nothingness of which John speaks is not 'ontological nothingness' and is not of the same order of the various nights of the spirit which are often graphically portrayed in modern literature and art. The latter are:

... death and despair, and ... 'destruction' of the spirit even unto its natural desire and its consubstantial taste for its own proper operative ends - a radical horror at its own life. (Maritain [1941]/1972:287)

While the trials of the passive purgation of the spirit are far worse than any experienced before in the Sanjuanist schemata, nevertheless they are not a cause for despair; on the contrary, they reflect the fact that the inflowing of God's light and wisdom is taking place. In contemporary psychological terminology, this painful stage is seen to be the rise of preconscious, subconscious, unconscious and unintegrated elements of the psyche into consciousness, there to be purified and cleansed. It is therefore the exhaustion of a previous stage of servitude to a lower range of significances, and a growth towards a new state of consciousness, leading to greater unification of the entire 
personality and a deeper maturation. Instead of being a sign of death and despair, it is a sign of life which shatters present horizons and leads to new vistas. The dark night can produce a high degree of moral and psychological integrity, and can even increase a person's physical stamina. Whereas the passive night of the senses trimmed the branches of the inherent imperfections, the passive night of the spirit completes the work and pulls up the roots. The fact that maturation and integration result from such intense suffering on the mystical way is a sound argument against those who would claim that mystical experience is regression or emotional instability. John's insights can be of value from a psychological point of view, because he does not speak about destroying human nature, but about grace building upon nature. Furthermore, he does not ignore the importance of the bodily and the sensual elements of the human being (Tyler 2010:92).

Maritain ([1941] 1972:288-280) suggests three ontological characteristics of the night of the spirit, (1) mystical experience through union of love, (2) transcendence of all techniques and (3) evangelical behaviour, or detachment of perfection. The latter, according to Maritain is not self-centred 'spiritual athleticism' but rather the perfection of love towards Another, whom the adherent loves more than self. Thus, death of ego effects the greater life of the Self. It is important to note that the precise delineation of the nights of sense and spirit is secondary to the recognition that the mystical journey requires progressive and ever more profound purification. The 'dark night of the soul' or the 'body-person' in terms of current psychological understanding, can be seen as a generic term referring to the whole discipline of interior 'naughting' which forms the bedrock of John's thought, and which leads to the fullness of life.

In addition, John's stark descriptions belie the fact that:

Not all experiences of the nights of the spirit are challenging. Even before one comes to the state of union one may have profound but not overwhelming experiences of God's love. In fact one definition of contemplation John employs is noticia amorosa - noticing love.... Sometimes these experiences are incredibly subtle and delicate, delighting the soul throughout; even, he says to the very points of our fingers. Other times this love is not so subtle. John uses the image of an assailing arrow or dart afire with the love of the Holy Spirit.... The soul, he says feels as though the entire universe is a sea of love in which it is engulfed. (Feldmeier 2006:58) ${ }^{20}$

A further consideration to be borne in mind concerns the experience of the dark night of sense and spirit in contemporary society, one vastly different from sixteenth century Spain. Although John's terminology may be foreign to modern ears, the concept of the night is not alien. As noted above, inter alia, art, literature, music and drama are means of

20.Feldmeier's observation alerts us to the fact that whilst John's schemata is developmental, this does not preclude variations in his mystical way. Indeed, John would be the first to refute the claim that the Spirit can be neatly categorised. (he spiritualities of John of the Cross and Buddhaghosa. Space does not allow for a discussion of his findings, but his approach is indicative of a greater understanding of the value of John in the light of diverse religious traditions (cf. Kourie 2013). reflecting an existential void, in which that which once had meaning now has none. The experience of the dark night can take place at several levels: personal disasters, such as bereavement, disappointment, failure, or even the quiet martyrdom of everyday life; old age; cosmic concerns, such as the destruction of the environment, the problem of evil including continuing wars andthe refugee crisis. All these serve to confront humanity with its finitude, and issue forth in basic questions concerning human existence. The misconception that the dark nights are only purely spiritual and interior ordeals experienced by cloistered monks and nuns needs to be dispelled. The purifying action of God in the midst of such trials is seen as much today as in John's time, and his counsels hold sway in the twenty-first century, as they did in the sixteenth.

\section{The unitive way}

Having followed the mystical path so far, the contemplative now enters into the unitive way. The deep and searing desire for union with God leads the devotee to the permanent state of spiritual marriage which is the 'highest state attainable in this life' (SC12, 8. Kavanaugh \& Rodriguez 1991:518). ${ }^{21}$ Spiritual marriage is 'incomparably greater than the spiritual betrothal, for it is a total transformation in the Beloved, in which each surrenders the entire possession of self to the other with a certain consummation of the union of love, [becoming] God through participation, insofar as this is possible in this life' (SC22:3. Kavanaugh \& Rodriguez 1991:560-561). This is illustrated by means of the resurrection myth, which is a '... summons to, and assurance of, new resurrection life for the disciple, wherein guilt, alienation, hostility and meaninglessness are transcended by deliverance, reconciliation, love and faith' (Gualtieri 1982:182). Finitude is transcended, and the deeper and richest levels of the personality come to light and freedom. The higher realms of consciousness are realised and the self is transformed and remade. This increase of strength enables the mystic to cope with often extraordinary and demanding circumstances which previously would have seemed insurmountable. Now, however, because of the inflowing life that is greater than that of the individual, there is, in alchemic terminology, a transmutation of the salt, sulphur and mercury of the personality into spiritual gold. The mystic is now in a state of abiding peace and emotional equilibrium, totally absorbed in the Divine. Such 'transformation in love occurs in this life; transformation in glory belongs to the life after this life' (Waaijman 2006:46). Transformation in love is a sketch of what is to come. 'However deep and thorough the transformation in love may be, it cannot in this life become complete transformation in glory. That is possible only when this life is relinquished in death' (Waaijman 2006:46).

\footnotetext{
21.Spiritual marriage is prefigured in the spiritual betrothal - the transition between the illuminative and the unitive paths, in which the purifying action of the Spirit the illuminative and the unitive paths, in which the purifying action of the Spirit facilitates a 'touch' of divinity, a proleptic of what is to come in the final union with the Divine. These 'divine rays' communicate a substantial knowledge of God in the inmost substance of the soul. There is an awareness of being 'clothed with delight and bathed in inestimable glory.. However, in the state of 'espousal' thes experiences are transitory. Nevertheless, the end is in sight and '...the contemplative feels like "a stone which is racing toward its centre"; the passing of these transitory "visits" leave him (sic) impatient and unsatisfied ...' (Payne 1982:177).
} 
The state of spiritual marriage in John's doctrine effects greater psychological harmonisation and integration than the previous states. Doohan (1995:78) delineates the effects of this union: inter alia, mutual rejoicing; peace; virtues; constancy; disinterest in whatever is not of God; seven degrees of this union; mutual surrender between God and the spouse; value of this loving union; growth in virtue; and longing for eternal union in the transformation of eternal life. Whereas previously there were periods of alternation between the presence and absence of God, the unitive stage is characterised by a certain permanent substantial union.

The new self glows love everywhere. John loved the metaphor of fire to describe this dissemination of love: ' ... love is never idle, it is always emitting flames everywhere like a blazing fire' (LF 1,8). The new self is the individual who has crossed oceans of delight, to realize that at each moment one's life is ultimately lived within the mysterious Other we call God'. (Perrin 2014:38)

Partaking directly in the divine nature, the mystic is deified, or transformed in God.22 'The Beloved lives in the lover and the lover in the Beloved .... This is the meaning of St Paul's affirmation: Vivo Autem, iam non ego; vivit vero in me Christus (I live, now not I, but Christ lives in me) [Gal 2:20]' (SC13, 8. Kavanaugh \& Rodriguez 1991:518). This is not to be confused with loss of differentiation, annihilation of the self and equality with the deity, but rather a sharing in the divine life, to the extent that the individual is an expression of divinity. According to Howells (2002):

The soul now understands itself as Christlike, that is, within the 'loving activity' of the Holy Spirit which is shared by the Father and the Son' and virtuous works proceed seamlessly from the interior union, as they did from Christ's own union with the Father. (Howells 2002:58)

The fact that the individual has faithfully followed the mystical path and reached the sublime state of spiritual marriage does not mean that this is the end of the journey and that all that remains is to bask in glory. This is far from the case. Mystical marriage leads to spiritual fruition and necessitates a return to the world, and an increase of activity (cf. Teilhard de Chardin 1968:116).

The material universe ... has produced us as creatures of reflection and action, and this creaturely nature mediates to us the presence of the mystical milieu. At the same time, we contribute to the ongoing creation of the universe and of Christ's body through our activity of creating or building. (Hefner 2011:92)

The history of mysticism is replete with examples, inter alia, Teresa of Avila (1515-1582) who, when more than 50 years of age, embarked on the reform of the Carmelite order; or Catherine of Siena (1347-1380) who after a period of intense withdrawal, dominated the political scene of her time, are well known. Thus, there is an increase in creative good works which often unite compassion with political insight,

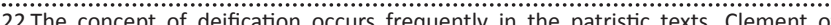
Alexandria states: 'God's Logos has become human that humankind might be able to grasp how it can attain to being God' (Protrepticus 1.9, in Pannikar 1989:193, n39). This central Christian doctrine has unfortunately been relegated to obscurity n39). This central Christian doctrine has unfortunately been relegated to obscurity
due to the fear that it might promote pantheism. pragmatic concerns, and economic progress. The goal of mysticism is

... therefore an everyday life that is experienced in the light of the mystical experience and is permeated by it.... The person who has passed through all the stages of mystical development no longer distinguishes between sacred and secular, church and stable, cloister and world, prayer and work, action and passivity, suffering and joy. To such a person, everything is holy ... (Jager 1987:50-51)

Whilst this loving transformation is, as noted above the highest degree of perfection that can be reached in this life, yet:

... with time and practice, love can grow deeper in quality ... and become more ardent.... Although the fire has penetrated the wood, transformed it, and united it with itself, yet as this fire grows hotter and continues to burn, so the wood becomes much more incandescent and inflamed, even to the point of flaring up and shooting flames from itself. (LF Prologue 3. Kavanaugh \& Rodriguez 1991:639)

\section{Value of John of the Cross for today}

Having discussed in some depth the Sanjuanist stages of the spiritual path, certain questions arise as we consider the value of this sixteenth century mystic for an era vastly different from his own. Inter alia, the following objections are worthy of note: Is not John's threefold path overly rigid and artificial? Are not the ascetical practices and techniques contrived and inhibitive? Are not the various stages with the concomitant phenomena open to subjective and arbitrary verification? Does not John's teaching on mystical marriage veer towards a heretical position of ontological identity with the Divine, which is contrary to theistic orthodoxy? In particular, is not the emphasis on detachment and the dark night too stark and negative, pointing to an impossible ideal? Whilst space does not allow for an in-depth response to each and every question, the following remarks will hopefully facilitate a greater understanding of the value of John's teaching for today.

Firstly, it has already been noted that the threefold path has not been universally accepted. Indeed theologians, such as Karl Rahner clearly reject this method. ${ }^{23}$ Contemporary spirituality suggests that individuals may find it helpful to pray contemplatively from the very beginning. The current rise of interest in meditation and centring prayer is a clear example of the latter. Opposition to what is considered an overly contrived schemata of the spiritual life has also resulted in an 'anti-technique', or what could be called a 'techniqueless technique' in which one lives truly in the present moment and in the perpetual flux of reality. Clearly, such a 'method-less' method suits many twenty-first century women and men who do not have the time or inclination to follow the Sanjuanist path. John also states that his teaching is not for everyone (A:Prologue, 9. Kavanaugh \& Rodriguez 1991:118). In addition, it is clear that mystical experience is not dependent on any particular schemata. Secondly, 23.cf. Rahner (1967) and the discussion of the 3 -fold way in Christianity, above. 
notwithstanding the aforementioned, there are those who find John's teaching of particular value in the field of psychospiritual development (cf. Tyler 2010:79-98). John's treatment of the dark night has been of particular relevance for an understanding and treatment of depression (Turner 1995; 1998; cf. May 2004). ${ }^{24}$ In addition, the asceticism that John recommends is to 'enhance the integration of the self ... and guide the ... transformative process that leads toward ultimate goals in life' (Perrin 2007:246). Thirdly, John's entire mystical schemata must be seen holistically; the various stages may well overlap, and the path is unique to each individual: 'God leads each one along different paths so that hardly one spirit will be found like another in even half its procedure' (LF 3.59. Kavanaugh\& Rodriguez 1991:697). John wishes to lead his readers to the summit, transformation: he is Doctor del Todo, Doctor of the All, in addition to being Doctor de la Nada, Doctor of Nothingness. "The many "nothings" (nadas) lead to "everything" (todo), even on a human level ... (and) spiritual freedom and real joy in the Life of the Spirit' (Doohan 1995:96). Fourthly, whilst the concept of mystical marriage $\mathrm{e}^{25}$ may sound strange to some, nevertheless for John, this is the outcome of his mystical reading of scripture, as noted above, with respect to Paul's statement, 'I live, yet not I, but Christ lives in me' (Gl 2:20).

Union with God implies a profound fulfilment of human potential. Both union and renewal of personality go together, in John's vision ...Having previously emptied oneself, an individual receives enjoyment and delight when filled with God. (F, 3,18) (Doohan 1995:95)

\section{Conclusion}

In line with many religious traditions that posit a way of purification and development in the spiritual life, John of the Cross illustrates the fact that an individual is often originally in a state of psychological, moral, physical and spiritual disequilibrium. By means of ascetic endeavour and efforts at self-reform, the person begins to move into a higher state of consciousness and a new contemplative mode of awareness, which ideally blossoms into the experience of enjoying God in the state of spiritual marriage. Although at first sight, John's teaching on the mystical way may appear daunting, on closer examination it becomes clear that in this corpus of writing the higher levels of transcendent possibility and realised human development are delineated with great perspicacity by John. Although the outlines of the pattern of Christian growth had been established for more than a thousand years before John penned his mystical ascent, nevertheless his crowning literary and mystical achievement is his systematic filling in of the salient details regarding the path of spiritual progress. Although it is readily accepted that mystical realisation is not limited to those who choose to follow a particular path, nevertheless, in the Sanjuanist

24.See also Peasgood (2007) for a very interesting study on the relevance of John of the Cross for Canadian Prairie Evangelical spirituality. Peasgood's research focusses on the importance of understanding John's teaching on the Dark Night particularly for a community whose tradition did not include mystical spirituality particularly for a com
(cf. 2007:2; 126-225).

25.Underhill ([1911] 1961:416) points out that mystics characterised by a transcendent/metaphysical approach speak more often of deification, whereas those following a more intimate/personal approach speak of spiritual marriage. journey, the psycho-spiritual energies generated harness the mind as it passes through the various gradients of the journey, effecting what could be called a 'voltage' of energy bursting onto the field of consciousness. There is a resurrection of the person, whereby finitude is transcended and higher and richer levels of consciousness come to light. This new ingression of energy empowers the mystic as she or he returns to the market-place. John describes the observable course of healthy spiritual development, based on his experience of guiding a large number of both cloistered sisters, brothers and lay persons of diverse personalities. The transforming union that he describes so profoundly effects enrichment and personal integration at all levels of the personality.

\section{Acknowledgements Competing interests}

The author declares that she has no financial or personal relationships which may have inappropriately influenced her in writing this article.

\section{References}

Arintero, J., [1951] 1978, The mystical evolution in the development and vitality of the church, Vol. II, Tan Publishers, Rockford, IL.

Blommestijn, H., Huls, J. \& Waaijman, K., 2000, The footprints of love. John of the Cross as guide in the wildnerness, Peeters, Leuven.

Borchert, B., 1994, Mysticism. Its history and challenge, Samuel Weiser, Inc., Cape Neddick, ME.

Carmody, D.L. \& Carmody J.T., 1996, Mysticism. Holiness east and west, Oxford University Press, New York.

Doohan, L., 1995, The contemporary challenge of John of the Cross. An introduction to his life and teaching, ICS Publications, Washington, DC.

Dupre, L., 1981, The deeper life, Crossroad, New York.

Eliade, M., 1969, Yoga, Princeton University Press, New York.

Feldmeier, P., 2006, Christianity looks east. Comparing the spiritualities of John of the Cross and Buddhaghosa, Paulist Press, New York.

Fowler, J., 1996, Faithful change, Abingdon Press, Nashville, TN.

Ganeri, M., 2012, 'Christian spirituality and Hinduism', in R. Woods \& P. Tyler (eds.), The Bloomsbury guide to Christian spirituality, pp. 229-239, Bloomsbury, London.

Green, D., 1986, 'St John of the Cross and the mystical unknowing', Religious Studies 22, 29-40. http://dx.doi.org/10.1017/S0034412500018011

Griffiths, B., 1995, River of compassion. A Christian commentary on the Bhagavad Gita, Continuum, New York.

Gualtieri, A., 1982, 'The resurrection of Jesus as transformational myth', Encounter 43, 177-183.

Hefner, P., 2011, 'Teilhard's spiritual vision of the mystical milieu', in J. Salmon \& J. Farina (eds.), The legacy of Pierre Teilhard de Chardin, pp. 79-94, Paulist Press, New York.

Heidegger, M., 1966, Discourse on thinking, Harper \& Row, New York.

Hense, E., 2011, 'The quest for interdisciplinary theories on spirituality', in E. Hense \& F. Maas (eds.), Towards a theory of spirituality, Studies in Spirituality, Supplement 22, pp. 5-14, Peeters, Leuven.

Howells, E., 2002, John of the Cross and Teresa of Avila. Mystical knowing and selfhood, Herder \& Herder, New York.

Jacobs, L., 1986, 'Judaism', in C. Jones, G. Wainwright \& E. Yarnold (eds.), The study of spirituality, pp. 491-497, SPCK, London.

Jager, W., 1987, The way to contemplation. Encountering god today, Paulist Press, New York.

Katz, S. (ed.), 1983, Mysticism and religious traditions, Oxford University Press, New York.

Kavanaugh, K. \& Rodriguez, O., 1991, The collected works of St. John of the Cross, ICS Publications, Washington, DC.

Kochumutomm, T., 2011, 'Journey in dark night', Journal of Dharma. Mystical Traditions 36(1), 15-38

Kourie, C., 1993, 'Myth and mysticism', in M. Clasquin, J.D. Ferreira-Ross, D. Marais \& R. Sadowsky (eds.), Myth and interdisciplinary studies, pp. 109-131, University of South Africa, Pretoria.

Kourie, C., 2011, 'Crossing boundaries: The way of interspirituality', Religion and Theology 18, 10-31. http://dx.doi.org/10.1163/157430111X613647 
Kourie, C., 2013, 'Discerning the mystical wisdom of the Bhagavad Gita and John of the Cross', in P.G.R. De Villiers (ed.), The spirit that guides. Discernment in the Bible and spirituality, Acta Theologica, Supplementum 17, pp. 247-270.
and

Kourie, C., 2015, 'Weaving colourful threads: A tapestry of spirituality and mysticism', HTS Teologiese Studies/Theological Studies 71(1), Art.\#3023, 9 pages. http://dx. doi.org/10.4102/hts.v71i1.3023

Kruger, J.S., 1989, Metatheism. Early Buddhism and traditional Christian Theism, University of South Africa, Pretoria.

Kruger, J.S., 2007, Turning-points in Buddhist mysticism and philosophy, Aurora Press, Pretoria.

Kurian, A., 2000, Ascent to nothingness. The ascent to God according to John of the Cross, St. Paul's Publishing, London.

Louth, A., 1989, Denys the Areopagite, Geoffrey Chapman, London.

Maritain, J., [1941]/1972, Ransoming the time, Gordian Press, New York.

May, G., 2004, The dark night of the soul. A psychiatrist explores the connection between darkness and spiritual growth, HarperSanFrancisco, New York.

McGinn, B., 2011, 'Comparative dynamics in the inter-religious study of mysticism', in E. Hense \& F. Maas (eds.), Towards a theory of spirituality, Studies in Spirituality, Supplement 22, pp. 81-95, Peeters, Leuven.

McGonigle, T., 1993, 'Three ways', in M. Downey (ed.), The new dictionary of Catholic spirituality, The Liturgical Press, Collegeville, MN.

Merton, T., 1981, The ascent to truth, Harcourt, Bruce and Co., New York.

Nasr, S.H. (ed.), 1987, Islamic spirituality: Foundations, Crossroad, New York.

Pannikar, R., 1989, The silence of god. The answer of the Buddha, Orbis, New York.

Pawlikowski, J., 2012, 'Christian spirituality and Judaism', in R. Woods \& P. Tyler (eds.), The Bloomsbury guide to Christian spirituality, pp. 250-260, Bloomsbury, London.

Payne, S.L., 1982, The philosopher and the mystic: An analysis of some contemporary philosophical approaches to mysticism in the light of the teachings of Saint John of the Cross, University Microfilms International, Ann Arbor, MI.
Peasgood, J., 2007, 'The relevance of John of the Cross (1542-1591) for Canadian prairie evangelical spirituality', Unpublished DTh thesis, University of South Africa, Pretoria.

Perrin, D.B., 2007, Studying Christian spirituality, Routledge, New York.

Perrin, D.B., 2014, 'The new self of John of the Cross', Vinayasadhana 1(1), 31-42.

Pierce, B., 2012, 'Christian spirituality and Buddhism', in R. Woods \& P. Tyler (eds.), The Bloomsbury guide to Christian spirituality, pp. 240-249, Bloomsbury, London.

Rahner, K., 1967, 'Reflections on the problem of the gradual ascent to Christian perfection', in The theological investigations, pp. 3-23, Darton, Longman \& Todd, London.

Teilhard de Chardin, P., 1968, The divine milieu, Harper \& Row, New York.

Turner, D., 1995, The darkness of god. Negativity in Christian Mysticism, Cambridge University Press, Cambridge.

Turner, D., 1998, 'St John of the Cross and depression', Downside Review 106 157-170.

Tyler, P., 2005, 'Triple way', in P. Sheldrake (ed.), The new SCM dictionary of Christian spirituality, pp. 626-627, SCM, London.

Tyler, P.M., 2010, St John of the Cross, Continuum, London.

Underhill, E., [1911]/1961, Mysticism. A study in the nature and development of man's spiritual consciousness, Dutton, New York.

Waaijman, K., 2006, 'Conformity in Christ', in P.G.R. De Villiers, C.E.T. Kourie \& C. Lombaard (eds.), The spirit that moves. Orientation and issues in spirituality, Acto Theologica, Supplementum 8, pp. 41-53.

Waaijman, K., 2008, 'Mystical perspectives in interreligious dialogue', in P.G.R. De Villiers, C.E.T. Kourie \& C. Lombaard (eds.), The spirit that empowers: Perspectives on spirituality, Acta Theologia, Supplementum 11, pp. 221-233.

Werblowsky, R., 1966, 'On the mystical rejection of mystical illuminations', Religious Studies 1(2), 177-184. http://dx.doi.org/10.1017/S0034412500002456 